ellers referatpreget tekst. Innholdet er preget av å være tilpasset britiske forhold. Det er en utstrakt bruk av forkortelser, noe som gjør teksten relativt tungt tilgjengelig. Et lovende forord diktert av professor sir Ara Darzi bøter ikke på disse forholdene, $\mathrm{i}$ hvert fall ikke for norske lesere.

Tatt $\mathrm{i}$ betraktning at den nesten er for stor til å falle bekvemt ned i en frakkelomme, men for liten til å kunne legges behagelig på en lesepult, vil jeg i utgangspunktet anbefale leserne å undersøke hvilke andre lomme- eller lærebøker i kirurgi for medisinstudenter og unge vordende kirurger som finnes på markedet.

\section{Noe nytt om personlighetsforstyrrelser?}

Emmelkamp PM, Kamphuis JH. Personlighetsstörningar

291 s, tab, ill. Lund: Studentlitteratur, 2009. Pris SEK 305

ISBN 978-91-44-05182-6

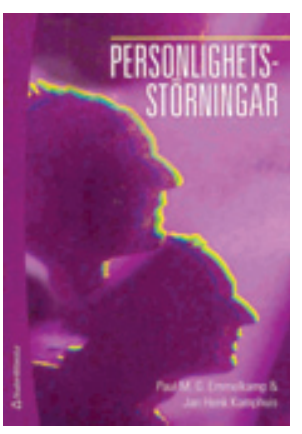

Med denne boken har de to nederlenderne Paul M. Emmelkamp og Jan Henk Kamphuis tatt mål av seg til å gi et oppdatert bidrag til litteraturen om personlighetsforstyrrelser, noe de har lyktes med.

Boken er inndelt i ni kapitler. Kapittel 1 gir en beskrivelse av personlighetsforstyrrelsene generelt, mens kapittel 2 tar for seg diagnostiske metoder. Deretter omhandles epidemiologi og forløp samt biologiske og psykologiske teorier. Kapittel 5 tar for seg de engstelige personlighetsforstyrrelsene (gruppe C), de neste tre tar gruppe B-personlighetsforstyrrelsene: ustabil (borderline), narsissistisk, hysterisk og antisosial personlighetsforstyrrelse, mens det siste tar de tre personlighetsforstyrrelsene innen gruppe A: paranoid, schizoid og schizotyp personlighetsforstyrrelse.

Allerede i kapittelinndelingen ser vi den samme tendensen som i litteraturen for øvrig. Gruppe B, spesielt ustabil personlighetsforstyrrelse, med sine 37 sider gis omtrent like mye plass som omtalen av gruppe $\mathrm{A}$ og $\mathrm{C}$ til sammen.

I normalbefolkningen er personlighetsforstyrrelsene innen gruppe $\mathrm{C}$ mest utbredt, mens i visse kliniske populasjoner vil ustabil personlighetsforstyrrelse som en av de dramatiske typene, både være hyppigere og mer synlig i det terapeutiske landskapet. Begge disse faktorene er medvirkende til at ustabil personlighetsforstyrrelse blir viet så stor oppmerksomhet, ikke minst innen forskning.

Selv om de forskjellige personlighetsforstyrrelsene har fătt ulik spalteplass, blir alle i hovedsak gjennomgått med klinisk beskrivelse, og det gis teoretiske refleksjoner omkring konstruktvaliditeten (prototypiske kvaliteter og overlapp med andre diagnosekategorier) samt nevroanatomiske og nevrofysiologiske/hormonelle aspekter. Til slutt kommer en grundig omtale av foreliggende terapiforskning. Et avsnitt om voldelighet hos personer med de forskjellige diagnosene er også inkludert, ikke bare hos dem man kunne forvente, men også blant pasienter i den engstelige kategorien. Psykopatbegrepet i relasjon til antisosial personlighetsforstyrrelse blir viet omtale i større grad enn det vi i norske fagmiljøer er vant til.

Et tema som kunne vært viet mer oppmerksomhet, er en mer systematisk gjennomgang av diskusjonen omkring akse I-/ akse II-problematikken, ikke minst for diagnosen ustabil personlighetsforstyrrelse. Hagop Akiskal, som har vært en sterk talsperson for å plassere borderlinetilstanden som en del av det bipolare spektrum på akse I, er bare så vidt nevnt med en referanse.

Prototypiske kvaliteter og overlapp med andre diagnosekategorier kunne vært mer systematisk fremhevet for alle personlighetsforstyrrelsene. For avhengig personlighetsforstyrrelse er dette aspektet best ivaretatt, for de andre i mindre grad, til tross for at det er publisert flere studier innen dette feltet for de fleste akse II-diagnosekategoriene, også flere norske studier. I omtalen av ustabil personlighetsforstyrrelse er antall kombinasjonsmuligheter for å oppnå diagnosen (krav om at fem av ni kriterier er oppfylt) feilaktig angitt å være 246. Det korrekte tallet er 256, som utledes etter en spesiell formel for det polytetiske prinsipp som DSM-IV er basert på. For de øvrige diagnosene er antall mulige kombinasjoner ikke angitt, ei heller om forekomsten av antall kriterier innen en diagnostisert populasjon bekrefter en kategoriell eller en dimensjonell struktur.

Layouten er tiltalende og oversiktlig, og den svenske oversettelsen er lettlest. Til tross for de nevnte mangler, bringer den ny kunnskap inn i fagfeltet og er leseverdig for alle som arbeider med pasienter med personlighetspatologi.

\section{Tore Gude}

Modum Bad

og

Avdeling for atferdsfag

Universitetet i Oslo

\section{Forskningsmetodikk på enkeltcellenivå}

Anselmetti D, red.

Single cell analysis

Technologies and applications. 258 s, tab, ill. Weinheim: Wiley-Blackwell, 2009. Pris EUR 96 ISBN 978-3-527-31864-3

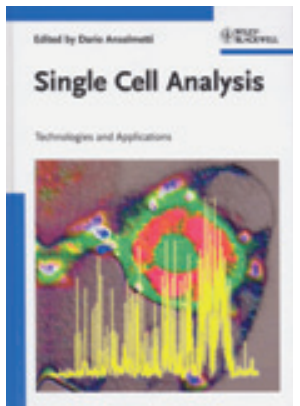

Vår medisinske forståelse blir mer og mer molekylær. Kunnskap om sykdomsmekanismer, diagnostikk og beslutningsgrunnlaget for ulike behandlingsmessige intervensjoner er i økende grad basert på

molekylærmekanistisk innsikt fremskaffet gjennom forskning med nye «omics»-teknologier som gir oversikt over genomet, transkriptomet, proteomet og metabolomet hos enkeltindivider. Analyser med slike teknologier har imidlertid tradisjonelt krevd mye materiale og har gjort at mange studier har vært kjørt på relativt store vevsbiter og tumorprøver og på blandinger av celler. De molekylære begivenhetene som er viktige i molekylærmedisinen, skjer i stor grad i en kontekst av én enkelt celle eller i samspillet mellom spesifikke enkeltceller. Man kan derfor miste mye relevant informasjon ved analyser av vevsbiter med flere anatomiske lag eller målinger på blandinger av ulike celletyper uten å kunne skille begivenheter i enkeltceller fra hverandre, noe en vevsbit fra nervesystemet eller en blodprøve med sirkulerende leukocytter, begge med et helt spekter av ulike subpopulasjoner, er eksempler på. Enkeltcelleanalyser er derfor nå tiltakende viktig som forskningsverktøy for å kunne gå fremover i molekylærmedisinsk forståelse, og den teknologiske utviklingen tillater nå i økende grad ulike sensitive analyser på enkeltcellenivå.

Denne metodeboken med Dario Anselmetti som redaktør gir en glimrende oversikt over et helt spekter av enkeltcelleanalyser innen molekylærbiologi, cellebiologi, systembiologi, genregulering, proteomikk, immunologi og onkologi. De ulike kapitlene spenner over mikroskopiteknikker som omfatter fluorescensmikroskopi, flerefotonanalyser, FRET-, FRAP-, TIRFanalyser, in situ-hybridisering, elektronog «atomic force»-mikroskopi og krysser over mot strukturbiologi med fremstilling av enkeltmolekyler samt mikroskopi på levende celler med egne typer markører. Videre beskrives enkeltcelleproteomikk, enkeltcellemassespektroskopi, enkeltcelleelektroforese, «high throughput»- og «high content»-analyser, bruk av mikrovæskestrøm og laserlys og optikk. Det er også kapitler om immunologiske enkeltcelle- 